
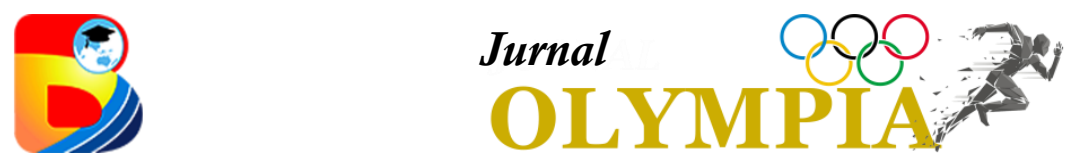

http://journal.binadarma.ac.id/index.php/olympia

\title{
Efektivitas Latihan Hand Grip dan Push Up Terhadap Passing Atas Bola Voli Siswa Sekolah Menengah Kejuruan Negeri 8 Palembang
}

\begin{tabular}{l}
\hline Info Artikel \\
\hline Sejarah Artikel: \\
Diterima Januari 2019 \\
Disetujui Februari 2019 \\
Dipublikasikan Maret \\
2019
\end{tabular}

Aulia Urahman ${ }^{1}$, Arif Hidayat ${ }^{2}$

Universitas Bina Darma, Indonesia ${ }^{1}$
Keywords: passing on volleyball, hand grip exercise, push up

\begin{abstract}
Abstrak
Tujuan penelitian ini untuk mengetahui efektivitas latihan hand grip dan push up dalam passing atas bola voli. Jenis penelitian ini adalah penelitian kuantitatif dengan pendekatan pre experimen-tal design yaitu dengan menggunakan desain Pre-test dan Post-test Group Design. Sampel yang di gunakan pada penelitian ini berjumlah 20 orang siswa ekstrakurikuler putra.Teknik pengumpulan data dalam penelitian ini menggunakan pretest, treatment dan posttest. Analisis data dalam penelitian ini akan menggunakan uji $\mathrm{t}$ (t-test). Uji $\mathrm{t}$ ini diterapkan dengan menggunakan uji hipotesis. Hasil penelitian ini didapat nilai t-hitung 1,6305, sedangkan t-tabel 1,327773. Sehingga t-hitung > t-tabel, yang berarti ada perbandingan antara efektivitas latihan Hand Grip dan Push Up terhadap peningkatan kemampuan Passing atas peserta ekstrakurikuler bola voli putra SMK Negeri 8 Palembang. Uji beda mean didapati mean pretest $=24,55$, mean post testpassing atas setelah latihan Hand Grip $=50$, sementara untuk mean total skor post-test passing atas setelah latihan Push $U p=45$ dari hasil tersebut disimpulkan bahwa ada perbandingan antara latihan hand grip dan latihan push up terhadap passing atas bola voli Siswa Sekolah Menengah Kejuruan Negeri 8 Palembang.
\end{abstract}

\begin{abstract}
The purpose of this study was to determine the effectiveness of hand grip training and push ups in volleyball passing. This type of research is quantitative research with a pre-experimental design approach, namely by using the Pre-test and Post-test Group Design. The sample used in this study amounted to 20 male extracurricular students. Data collection techniques in this study used pretest, treatment and posttest. Data analysis in this study will use the t test (t-test). This $t$ test is applied using a hypothesis test. The results of this study obtained t-count value of 1.6305, while t-table of 1.327773. So that t-count>t-table, which means there is a comparison between the effectiveness of the Hand Grip and Push
\end{abstract}


Up exercises on increasing Passing abilities for male volleyball extracurricular participants at SMK Negeri 8 Palembang. The mean difference test found the mean pretest $=24.55$, mean post testpassing top after exercise Hand Grip $=50$, while for the mean top total post-testpassing score after Push Up training $=45$ from the results it was concluded that there was a comparison between hand grip training and push up training on volleyball passing over at the Vocational High School Students of Palembang 8.

Alamat korespondensi: Jl. Jend Ahmad Yani No 3 Seberang Ulu 1 Kota Palembang Sumatera Selatan

E-mail: muhammadauliaurrahman227@gmail.com

\section{PENDAHULUAN}

Permainan Bola voli di ciptakan pada tahun 1895, oleh seorang Pembina pendidikan jasmani pada Yuong Men Christian Association (YMCA) di kota Holyoki, Massachusetts, Amerika Serikat. Nama permainan ini semula disebut dengan "Minonette" yang hampir serupa dengan permainan badminton. Permainan Bola voli di Indonesia sendiri saat ini sangat pesat di lapisan masyarakat, sehingga muncullah klubklub di kota besar di seluruh Indonesia. Dengan dasar itulah pada tanggal 22 Januari 1955 PBVSI (Persatuan Bola Voli Seluruh Indonesia) didirikan di Jakarta bersamaan dengan kejuaraan nasional yang pertama. Dengan adanya PBVSI ini perkembangan Bolavoli di Indonesia jauh lebih maju karena ada suatu organisasi yang bertujuan untuk mengembangkan Bola voli dari pusat, daerah, sampai ke plosok tanah air (Santosa (2017:77-78).

Sebagai permainan yang telah memasyarakat, permainan bola voli memiliki peraturan serta teknik-teknik dasar yang sudah semestinya dikuasai baik untuk kalangan pemula maupun kalangan profesional salah satunya adalah teknik Passingg atas (Waluyo, 2012:15).

Passing Atas, teknik ini lebih mengutamakan kekuatanjari-jemari kedua tangan. Biasanya, teknik ini lebih dipilih pada saat seorang pemain hendak melakukan umpan sebelum dilakukan pukulan terakhir atau smash. Pemain yang dituntut memiliki keterampilan lebih dalam teknik ini adalah mereka yang berposisi sebagai tosser atau pengumpan. Seorang tosser harus bisa memberikan umpan yang memanjakan pemain lain untuk melakukan smash secara sempurna Witono Hidayat (2017: 45).

Berdasarkan hasil pengamatan peneliti disekolah SMK Negeri 8 Palembang siswa putra Ekstrakurikuler, masih banyak yang belum sepenuhnya menguasai teknik dasar permainan bola voli yang baik dan benar khususnya teknik dasar passing atas. Banyak siswa saat melakukan passing melakukan kesalahan seperti, tangan terlalu lurus dan terlalu rapat, kaki terlalu berdiri dengan kaku, hingga gerakan kaki yang kurang gesit. Menurut Witono Hidayat (2017 : 46) untuk 
melakukan teknik passing atas yang benar adalah kedua kaki harus sedikit ditekuk untuk membantu menghasilkan lontaran secara baik. Kedua tangan berada disamping dengan posisi telapak tangan membuka. Pada saat bola datang, telapak tangan menghadap ke arah bola dan menyentuh dengan ujung jari.

Untuk dapat melakukan passing atas dengan baik, diperlukan berbagai macam latihan diantaranya latihan hand grip dan push up. Hand Grip adalah jenis latihan yang bertujuan meningkatkan kemampuan otot atau sekelompok otot untuk melakukan satu kali kontraksi secara maksimal melawan tahanan atau beban. Secara mekanis kekuatan otot di definisikan sebagai gaya (force) yang dapat dihasilkan otot atau sekelompok otot dalam suatu kontraksi maksimal Widiastuti (2017: $75)$.

Permainan bola voli diciptakan oleh William G. Morgan pada tahun seorang guru pendidikan jasmani 1895 di holyoke (Amerika bagian timur). William G. Morgan adalah seorang pembina pendidikan jasmani pada Young Men Christain Association (MCA) Sukirno dan Waluyo (2012: 13)

Sukirno dan Waluyo (2012: 8) mengatakan bahwa permainan ini dimainkan oleh dua tim yang masing-masing terdiri dari 6 (enam) orang pemain dan bertanding mendapatkan poin mencapai angka 25 terlebih dahulu. Dalam sebuh tim, terdapat 4 peran penting, yaitu tosser (atau setter), spiker (smash), libero, dan defender (pemain bertahan).

\section{Passing Atas}

Teknik ini berbeda dengan teknik passing bawah. Pada teknik ini, lebih mengutamakan kekuatan jari-jemari kedua tangan. Biasanya, teknik ini lebih dipilih pada saat seorang pemain hendak melakukan umpan sebelum dilakukan pukulan terakhir atau smash. Pemain yang dituntut memiliki keterampilan lebih dalam teknik ini adalah mereka yang berposisi sebagai tosser atau pengumpan. Seorang tosser harus bisa memberikan umpan yang memanjakan pemain lain untuk melakukan smash secara sempurna Witono Hidayat (2017: 45).

Seorang tosser dituntut untuk bisa memberikan umpan terbaik dari setiap posisi. Karena dalam permainan voli ini, tujuan akhirnya adalah pukulan yang tajam yang disebut dengan smash. Smash ini bisa di lakukan apabila mendapatkan umpanan yang baik. Bila umpanan yang diberikan tosser kurang sempurna, maka tidak akan bisa menghasilkan peluang untuk menciptakan smash yang mematikan.

Cara melakukan passing atas menurut Waluyo (2012:15), jari-jari tangan terbuka lebar dan kedua tangan membentuk mangkuk hampir saling berhadapan. Sebelum menyentuh bola, lutut sedikit ditekuk hingga tangan berada di maka setinggi hidung. Sudut antara siku badan $>45^{\circ}$. Bola disentuh dengan cara meluruskan kaki dan tangan.

Passing atas sebuah operan overhead yang anda lakukan untuk menempatkan bola pada suatu posisi kepada penyerang. Operan 
ini terutama dilakukan oleh pengumpan, tetapi dapat juga digunakan oleh pemain lain gerakan dan benar.

Tangan ditekuk ke belakang dan sedikit ke sebelah dalam, punggung tangan dan lengan bawah harus membentuk sudut hampir 90 derajat. Ujung jari-jari kedua tangan saling dihadapkan, tetapi tanpa menyebabkan siku kedua tangan terpisah terlalu jauh.Jari dan telapak tangan membuat bentuk mangkok. Jari tangan terbuka secara wajar dan agak dibengkokkan.

Salah satu faktor yang menentukan keberhasilan seseorang dalam melakukan passing atasadalah kekuatan otot, untuk melatih kekuatan otot tersebut bisa dengan melakukan beberapa latihan, namun pada kesempatan ini yang akan dibahas adalah latihan forwardhand grip dan push up.

\section{Latihan Forward Hand Grip.}

Forward hand grip merupakan jenis latihan jenis secara keseluruhan dan tidak secara satu-persatu dengan cara menggenggam hand grip kemudian genggaman tangan digerakkan ke bawah (gerak fleksi) sehingga kontaksi otot terjadi di jari-jari tangan dan juga pergelangan tangan.cara melakukannya adalah sebagai berikut: 1) Boleh dilakukan dengan duduk atau berdiri, jika dengan duduk taruh siku di atas paha, 2) Hadapkan telapak tangan kebawah kemudian pegang hand grip, 3) gerakkan pergelangan tangan kebawah (fleksi) dan kembali ke posisi awal. Latihan dengan menggunakan jenis latihan forward hand grip dapat mempengaruhi kualitas otot.
Latihan ini mengaktifkan otot fleksor.Hal ini menyebabkan pengaruh peningkatan kekuatan kekuatan genggaman tangan dan kelentukan otot-otot pada pergelangan tangan, terutama berpengaruh besar terhadap otot fleksor, sehingga dapat meningkatkan hasil passing atas.

\section{Latihan Push-Up}

Push-up adalah suatu jenis senam kekuatan yang berfungsi untuk menguatkan otot bisep maupun trisep. Posisi awal tidur tengkurap dengan tangan kanan disisi kanan kiri badan, Kemudian badan didorong keatas dengan kekuatan tangan, posisi kaki dan badan tetap luruh atau tegap, setelah itu badan diturunkan dengan tetap menjaga kondisi badan dan kaki tetap lurus. Badan turun tanpa menyentuh lantai atau tanah. Naik lagi dan lakukan secara berulang. Tentunya dengan melakukan push-up, maka tubuh kamu akan memerlukan energi yang banyak.

Menurut Harsono (2015: 78-79) salah satu bentuk latihan dengan berat badan sendiri adalah push-up (telungkup dorong angkat badan), latihan ini bertujuan untuk melatih kekuatan dan daya tahan otot lengan. Adapun cara melakukannya adalah: "Tidur telungkup, kedua kaki rapat lurus ke belakang dengan ujung kaki bertumpu pada lantai. Kedua telapak tangan menapak dilantai disamping dada, jari-jari menghadap ke depan, siku lurus turunkan badan sampai kedu siku menekuk,posisi kepala, badan, dan tungkai berada dalam satu garis lurus badan di angkat kembali ke atas kedua lengan lurus, posisi 
kepala, badan, dan tungkai tetap lurus Lakukan gerakan ini berulang- ulang". Menurut Sukadiyanto (2010: 19) latihan pushup merupakan jenis kontraksi isotonik yang meningkatkan ketegangan otot pada saat otot dalam keadaan memanjang dan memendek yang melibatkan gerak persendian.

\section{METODE PENELITIAN}

\section{Jenis dan Desain Penelitian}

Metode yang digunakan dalam penelitian ini adalah penelitian kuantitatif Metode penelitian Kuantitatif adalah metode penelitian yang berlandaskan pada filsafat positivisme, digunakan untuk meneliti pada populasi atau sampel tertentu, pengumpulan data menggunakan instrumen penelitian, analisis data bersifat kuantitatif/statistik, dengan tujuan untuk menguji hipotesis yang telah ditetapkan, (Sugiyono, 2011: 8). Penelitian ini merupakan penelitian pre experimen-tal Design yaitu dengan menggunakan desain Pre-test dan Post-test Group Design.

Dalam desain ini observasi di lakukan sebanyak 2 kali yaitu sebelum eksperimen dan sesudah eksperimen. Observasi yang dilakukan sebelum (eksperimen 1) disebut pretest(sebelum diberi perlakuan), dan observasi sesudah (eksperimen 2) disebut posttest (setelah diberi perlakuan). Dengan demikian hasil perlakuan dapat diketahui lebih akurat, karena dapat membandingkan dengan keadaan sebelum diberi perlakuan Suharsimi Arikunto (2010: 306-307).

\section{Populasi dan Sampel}

Populasi dalam penelitian ini adalah siswa Ekstrakurikuler SMK Negeri 8 Palembang.

Tabel 1. Populasi

\begin{tabular}{|c|c|c|c|c|}
\hline \multirow[t]{2}{*}{ No } & \multirow[t]{2}{*}{ Kelas } & \multicolumn{2}{|c|}{$\begin{array}{c}\text { Siswa yang } \\
\text { mengikuti } \\
\text { ekstrakurikuler }\end{array}$} & \multirow[t]{2}{*}{ Jumlah } \\
\hline & & Putra & Putri & \\
\hline 1 & $12 \mathrm{TKJ}$ & 3 & 1 & 4 \\
\hline 2 & $12 \mathrm{ADM}$ & 4 & 2 & 6 \\
\hline 3 & $11 \mathrm{TJK}$ & 3 & 2 & 5 \\
\hline 4 & $11 \mathrm{AK}$ & 2 & 2 & 4 \\
\hline 5. & $10 \mathrm{TKJ}$ & 8 & 1 & 9 \\
\hline & Jumlah & 20 & 8 & 28 \\
\hline
\end{tabular}

Sumber : SMK Negeri 8 Palembang

Penelitian ini menggunakan teknik Purposive Sampling. Peneliti menggunakan teknik pengambilan sampel ini dikarenakan ada beberapa alasan yaitu:

1. Cara passing atas bola voli siswa yang belum baik.

2. Belum pernah mengikuti perlombaan di tingkat Daerah.

Berdasarkan pertimbangan tersebut, di gunakan sampel Purposive Sampling dari populasi sebanyak 28 siswa Ekstrakurikuler SMK Negeri 8 Palembang, sedangkan jumlah sampel yang di gunakan pada penelitian ini berjumlah 20 orang siswa ekstrakurikuler putra.

Tabel 2. Sampel

\begin{tabular}{|c|l|c|c|}
\hline No & \multicolumn{1}{|c|}{ Kelas } & $\begin{array}{c}\text { Siswa } \\
\text { Putra }\end{array}$ & Jumlah \\
\hline 1 & 12 TKJ & 3 & 3 \\
\hline 2 & 12 ADM & 4 & 4 \\
\hline 3 & 11 TJK & 3 & 3 \\
\hline 4 & 11 AK & 2 & 2 \\
\hline 5. & 10 TKJ & 8 & 8 \\
\hline \multicolumn{3}{|c|}{ Jumlah } & $\mathbf{2 0}$ \\
\hline
\end{tabular}

Sumber : SMK Negeri 8 Palembang 


\section{Teknik Pengumpulan Data}

Teknik pengumpulan data dalam penelitian ini menggunakan pretest, perlakuan treatment dan posttest. Hasil dari pretest dan posttest akan ditabulasi sesuai dengan nilai yang diperoleh dari siswa putra ektrakurikuler SMK Negeri 8 Palembang. Instrumen penelitian yang digunakan adalah tes passing atas bola voli, pengukuran awal (pretest) maupun pengukuran akhir (posttest).

\section{Teknik Analisis Data}

\section{Uji Normalitas}

Uji normalitas dilakukan sebagai bahan pertimbangan yang digunakan untuk menguji normalitas data, Untuk menguji apakah data tersebut berdistribusi normal, maka digunakan Uji Liliefors.

\section{Uji Homogenitas}

Uji homogenitas dalam penelitian ini menggunakan uji varian terbesar dibanding varian terkecil menggunakan tabel $\mathrm{F}$.

$$
\mathrm{F}_{\text {hitung }}=\frac{\text { Varian terbesar }}{\text { Varian terkecil }}
$$

\section{Uji Hipotesis}

$$
\mathrm{t}=\frac{M d}{\sqrt{\frac{\sum x^{2} d}{N(N-1)}}}
$$

\section{HASIL DAN PEMBAHASAN}

Hasil uji normalitas untuk data pretest adalah 0,55 , berada diantara $(-1)$ dan $(+1)$ sehingga data pretest berdistribusi normal. Sementara untuk data posttest kelompok dengan latihan hand grip adalah $-0,12$, berada diantara (-1) dan (+1) sehingga data posttest berdistribusi normal. data posttest kelompok latihan push up adalah 0,52 , berada diantara (1) dan (+1) sehingga data posttest berdistribusi normal.

Hasil Uji homogenitas didapat nilai Chi Kuadrat dengan $\mathrm{dk}=1$ dan $\alpha=0,05$ didapat bahwa $\times 2(0,95)(1)=3,84$ dan xhitung = 27,657. Syarat sampel homogen apabila x2hitung $<$ xtabel, didapat $-27,657<3,84$. Jadi sampel berasal dari populasi yang homogen.

Hasil t-hitungyang diperoleh adalah 1,6305. Sedangkan ttabel adalah t0.95 (20-1) yang didapat dari tabel distribusi $\mathrm{t} \mathrm{dk}=19$ dan taraf kepercayaan 95\% $(\alpha=0,05)$. $=1,327773$. Sehingga thitung $>$ ttabel dengan demikian tolak hipotesis Ho yang menyatakan tidak ada perbandingan efektivitas latihan Hand Grip dan Push Up terhadap peningkatan kemampuan Passing atas peserta ekstrakurikuler bola voli putra SMK NEGERI 8 Palembang. Terima Ha yang menyatakan ada perbandingan antara efektivitas latihan Hand Grip dan Push Up terhadap peningkatan kemampuan Passing atas peserta ekstrakulikuler bola voli putra SMK negeri 8 Palembang.

Hasil uji koefisiensi korelasi latihan push up diperoleh $r=0,21$ yang berarti latihan push up memiliki hubungan yang rendah terhadap passing atas. Hasil uji Determinasi (R2) diperoleh nilai 0,0441 yang berarti latihan push up memiliki kontribusi sebesar $0,4 \%$ terhadap passing atas. 
Hasil uji koefisiensi korelasi latihan Hand Grip diperoleh $r=0,40$ yang berarti latihan hand grip memiliki hubungan yang cukup kuat terhadap passing atas. Hasil uji Determinasi (R2) diperoleh nilai 0,16 yang

Latihan dengan menggunakan jenis latihan push updapat mempengaruhi kualitas otot. Latihan ini mengaktifkan otot fleksor.Hal ini menyebabkan pengaruh peningkatan kekuatan kekuatan genggaman tangan dan kelentukan otot-otot pada pergelangan tangan, terutama berpengaruh besar terhadap otot fleksor, sehingga dapat meningkatkan hasil passing atas.

Dari hasil analisa data didapati didapati mean pretes yakni 24 , sementara mean post testpassingatas setelah latihan Hand Grip = 50, untuk itu dapat ditarik kesimpulan bahwa adanya efektivitas latihan hand grip pada passing atas. Sehingga penelitian ini dapat memberikan masukan pembina dan atlit olahraga bola voli agar meningkatkan kemampuan passing atas siswa melalui latihan hand grip, tetapi tentunya diperlukan juga variasi-variasi latihan agar tidak membosankan.

\section{Pembahasan}

1. Latihan Hand Grip Memiliki Efektivitas Terhadap Passing Atas Peserta Ekstrakurikuler Bola voli Putra SMK Negeri 8 Palembang

Latihan hand grip merupakan bentuk latihan yang efektif untuk meningkatkan kualitas/kekuatan otot lengan dan jari. Karena arah gerakan latihan forward handgrip membentuk gerakan arah otot fleksor. Arah gerakan latihan forward handgrip membentuk gerakan arah parabola yang mirip dengan arah gerakan overhead lob sehingga otot yang bekerja juga sama. Hal ini yang akan menjadi faktor yang mempengaruhi peningkatan kekuatan genggaman tangan dan kelentukan otot-otot pada pergelangan tangan. Kekuatan genggaman tangan dan kelentukan pergelangan mempunyai peranan penting dalam bola voli, sehingga dapat meningkatkan hasil passing atas.

Dari hasil analisa data didapati mean pretes yakni 24,55, sementara mean post test passing atas setelah latihan Hand Grip $=50$, untuk itu dapat ditarik kesimpulan bahwa latihan hand grip memiliki efektivitas terhadap passing atas.

2. Latihan Push Up Memiliki Efektivitas Terhadap Passing Atas Peserta Ekstrakurikuler Bola voli Putra SMK Negeri 8 Palembang

Latihan push up memiliki efektivitas terhadap hasil passing atas dalam permainan bola voli, dikarenakan push up adalah suatu jenis senam kekuatan yang berfungsi untuk menguatkan otot bisep maupun trisep. Untuk bisa menghasilkan passing atas yang baik diperlukan kekuatan otot-otot tersebut selain itu teknik dasar passing atas menyerupai teknik dasar push up.

Dari hasil analisa data didapati didapati mean pretes yakni 24,55 sementara mean post 
test passing atas setelah diberi latihan Push up $=45$, untuk itu dapat ditarik kesimpulan bahwa adanya efektivitas latihan push up pada passing atas.

3. Latihan hand grip lebih efektif Terhadap Passing Atas Peserta Ekstrakurikuler Bola voli Putra SMK Negeri 8 Palembang

Latihan hand grip lebih efektif terhadap passing atas dikarenakan gerakan forward hand grip memiliki beberapa manfaat yakni, melatih telapak tangan menjadi lebih kuat dan memiliki daya cengkraman yang kuat. Cengkraman yang kuat ini bermanfaat untuk menahan dan melempar bola pada gerakan passing atas, selain melatih telapak tangan gerakan forward hand grip dapat mengeraskan, menguatkan dan membentuk otot tangan dan lengan yang sangat dibutuhkan untuk bisa menghasilkan passing atas yang maksimal. Jika dibanding dengan latihan push up latihan forward hand grip lebih diminati oleh siswa dikarenakan latihan ini menggunakan alat sehingga membuat siswa tidak cepat merasa jenuh dan tertantang untuk bisa melakukan latihan ini.

Dan dari hasil uji beda mean posttest latihan hand grip $\neg 50$ dan mean posttest latihan push up $=45$. Dengan demikian dapat disimpulkan bahwa latihan dengan hand grip lebih efektif dibanding latihan push up .

Dari penjelasan diatas, dapat diasumsikan bahwa atihan forward hand grip lebih efektif disbanding latihan push up dikarenakan latihan ini menggunakan alat yang mamberikan tantangan tersendiri bagi para siswa untuk bisa melakukannya, selain itu hasil dari latihan ini dapat memperkuat cengraman, memperkuat otot tangan dan lengan yang dibutuhkan saat melakukan passing atas.

\section{SIMPULAN}

Berdasarkan penelitian tentang Efektivitas Latihan Hand Grip Dan Push-Up Terhadap Peningkatan Kemampuan Passing Atas Bola voli Peserta Ekstrakurikuler Putra SMK Negeri 8 Palembang, diperoleh hasil sebagai berikut :

1. Latihan Hand Grip memiliki efektivitas terhadap passing atas peserta ekstrakurikuler bola voli putra SMK NEGERI 8 Palembang.

2. Latihan Push Up memiliki efektivitas terhadap Passing atas Peserta ekstrakurikuler bola voli putra SMK Negeri 8 Palembang,

3. Latihan hand grip lebih efektif terhadap passing atas bola voli Peserta Ekstrakurikuler Putra SMK Negeri 8 Palembang, didapati mean posttest latihan hand grip $\neg 50$ dan mean posttest latihan push up $=45$.

\section{DAFTAR PUSTAKA}

Arikunto, Suharsimi. 2010. Prosedur Penelitian Suatu Pendekatan Praktek. Jakarta: Rineka Cipta.

Giriwijoyo, Santosa. 2017. Fisiologi Kerja

Dan Olahraga. Jakarta: PT RajaGrafindo Persada.

Hidayat, Witono. 2017. Buku Pintar Bola Voli. Jakarta: Anugrah. 
Harsono. 2015. Kepelatihan Olahraga.

Bandung: PT Remaja Rosdakarya.

Nurhasan. 2001. Tes dan Pengukuran Dalam pendidikan jasmani. Jakarta: Badan Proyek Pembinaan Olahraga.

Sugiyono. 2011. Metode Penelitian

Kuantitatif, Kualitatif, Dan R\&D.

Bandung: Alfabeta.

Sukadiyanto. (2010). Pengantar Teori Dan

Metodologi Melatih Fisik. Bandung:

CV Lubuk Agung.

Sukirno, Waluyo. 2012. Cabang Olahraga

Bola Voli. Palembang: Unsri Press.

Waluyo, 2012. Serba Serbi Bola Voli. Jakarta:

Akademi Presindo

Widiastuti. 2017. Tes Dan Pengukuran

Olahraga. Jakarta: PT RajaGrafindo

Persada. 